\title{
UNDERSTANDING LOCAL COMMUNITY IN MANAGING SUSTAINABLE TOURISM AT BALURAN NATIONAL PARK - INDONESIA
}

\author{
Agus PURNOMO* \\ Universitas Negeri Malang, Social Studies Program, \\ Faculty of Social Science, Indonesia, e-mail: agus.purnomo.fis@um.ac.id \\ Idris IDRIS \\ Universitas Negeri Malang, Social Studies Program, \\ Faculty of Social Science, Indonesia, e-mail: idris.fis@um.ac.id \\ Bayu KURNIAWAN \\ Universitas Negeri Malang, Social Studies Program, \\ Faculty of Social Science, Indonesia, e-mail: bayu.kurniawan.fis@um.ac.id
}

\begin{abstract}
Citation: Purnomo, A., Idris, I., \& Kurniawan, B. (2020). UNDERSTANDING LOCAL COMMUNITY IN MANAGING SUSTAINABLE TOURISM AT BALURAN NATIONAL PARK INDONESIA. GeoJournal of Tourism and Geosites, 29(2), 508-520. https://doi.org/10.30892/gtg.29210-485
\end{abstract}

\begin{abstract}
Tourism is one of the most effective solutions to overcome poverty in rural communities. The economic benefits derived from the diversity of livelihoods are a reason for them to preserve their environment - the research gap in this paper aimed at sustainable tourism in the tourism management community group. Design research used to explain how community understanding in sustainable tourism management is descriptive qualitative. The survey was carried out in three villages supporting the Baluran National Park. In total, there were 53 data collected by interview. The analysis shows that sustainable tourism based on reasons for a sense of ownership of the surrounding environment. This knowledge generates the economic benefits they get from providing tourist services. Changes in managerial patterns for the management of Baluran National Park, in the form of service restrictions, provide opportunities for the community to be involved in tourism activities. In this case, support from the government can be a catalyst for tourism development. The result is an improvement in the quality of life of the people.
\end{abstract}

Key words: sustainable tourism, community, buffer villages, national park

\section{INTRODUCTION}

The focus of the study in this paper is how community groups manage sustainable tourism. Tourism is one of the most effective methods of alleviating poverty (Croes, 2014)

\footnotetext{
* Corresponding author
} 
in traditional community groups in the form of opportunities for the diversity of livelihood sources that are accessible to them (WTO, 2002; Lee, 2011; Lepp, 2007). Tourism developed by communities will indirectly increase the economic level (Lee \& Jan, 2019), and has been proven in various developing countries (Lepp, 2007; Dodds et al., 2018). Potential forms of tourism are managed by communities that present the unique local culture of rural communities (Wang et al., 2016; Thomson et al., 2016; Reggers et al., 2016). The concept of sustainable rural tourism began to develop in the buffer zone of Baluran National Park in 2015. This park is part of the Ijen-Baluran National Strategic Area (KSPN). Among the three national parks in the East Java region, IjenBaluran KSPN has a higher and more diverse visit pattern than Bromo Tengger Semeru National Park (Purnomo et al., 2019) and Gunung Sewu Pacitan GeoPark.

The development of tourism using community-based concepts will trigger the development of existing facilities in the village, such as roads or parks. The impact of improving the quality of life they feel will build knowledge to preserve their social and physical environment (Brunt \& Courtney, 1999). Tourism visits with special cultural interests increase the cultural preservation efforts of communities (Ruiz-Ballesteros, 2011; Wearing et al., 2010; Lee et al., 2013; Yachin \& Ioannides, 2020). On that basis, community-based tourism has a vital role in improving welfare because of its role in sustainable community development. However, of all the positive things that have presented, there are negative impacts from local community tourism activities, such as rising living costs (Lee \& Back, 2006), income distribution inequality (Alam \& Paramati, 2016), comfortable wages for workers with low skills (Davidson \& Sahli, 2015), deterioration in the quality of the physical and social environment (Bowers, 2016; Torkington et al., 2020), and increasing crime (Lee \& Back, 2006). The negative impacts that have described have the potential to damage the quality of the physical or social environment. These conditions will hamper the aspects of tourism sustainability. To achieve tourism sustainability, reducing negative impacts through community efforts or government support is needed (Lee \& Jan, 2019; Croes, 2014). This paper will explain how the process of communities in understanding sustainable tourism management.

\section{LITERATURE REVIEW}

Most of the conservation literature view community as a small spatial unit, a homogeneous social structure with shared norms and interests (Agrawal \& Gibson, 1999; Olsder \& Donk, 2006). Although the current literature on tourism development has noted that communities are central to sustainable tourism development, they rarely devote much attention to analyzing community concepts or how communities affect outcomes. Communities are groups of people with a common identity and who may be involved in various aspects related to livelihoods; they also have strong links with the area culturally, socially, economically and spiritually (Scherl \& Edwards, 2007).

The community is the main driving force of tourism; this means they can enhance tourism development (Olsder \& Donk, 2006). The development of tourism in the community can better explain using two concepts, namely sustainable tourism and sustainable development. The World Tourism Organization defines sustainable tourism as a tour that leads to the management of all resources in such a way that economic, social and aesthetic needs can be filled while maintaining cultural integrity, important ecological processes, biodiversity and life support systems (Shah et al., 2002). Therefore, tourism development can be meaningless if the community does not obtain the socio-economic and environmental benefits. The community is already familiar with the environment used as a tourist location. Historically, they coexisted with the main tourist areas (Bushell \& McCool, 2007). Therefore, his involvement in tourism 
development cannot ignore because of their important role. Their involvement in tourism development is very important in bridging the gap between governance and the use of resources in a tourist destination (Jamal \& Stronza, 2009). Apart from the economic contribution that can obtain from tourism, their involvement can also benefit tourism development because they can create effective environmental management that built on indigenous, local and scientific knowledge, economic development, social empowerment, protection of cultural heritage, the creation of interpretive experiences, and nature-based learning tours and cross-cultural appreciation (Jamal \& Stronza, 2009).

The role of the community as a provider of the main components of tourism cannot be separated from their basic knowledge of the surrounding environment, especially in buffer villages around National Park. The main components in tourism include attractions, amenities, and accommodation (Inskeep, 1991). The attraction is a major element in attracting tourists and is the main reason for them to come back again (Vengesayi, 2003). The form can vary, such as nature, culture, routine events, or artificial (Abdulhaji \& Yusuf, 2016). There are two conditions so that attractions can hold tourists to spend more time, namely, activities and objects (Soekadijo, 2003). The attraction is the most important element in tourism activity because it is a basic reason for tourists to travel (Purnomo \& Listyo, 2016). In addition to attractions, supporting facilities are needed to support and facilitate potential tourists to enjoy all the attractions above. Facilities to go to or at tourist sites are not the main factors that stimulate tourist arrivals, but their absence can prevent tourists from enjoying tourist attractions (Burkart \& Medlik, 1974). Own amenities include amenities and accommodations. Amenities are everything in the form of facilities that support the convenience of tourists in carrying out activities in an area/region/tourist attraction while accommodation is a whole component that supports the movement of tourists in the form of transportation modes/routes, types of transportation, roads leading to tourist attractions, and directional signs.

On the one hand, tourism development is believed to be like other industries that contribute to environmental destruction. While on the other hand, with proper planning and management, tourism can improve the environment and be a positive change (Walmsley et al., 1983). Positive changes include improving facilities and infrastructure, while negative changes include disruption to people's lives through noise, pollution, garbage, vandalism and crime. The extent of the change depends on the tourist destination and the nature of the tourism activity occurring, while the pace of development, the size of the tourism industry and the importance of tourism to the local economy are also important elements. Changes that occur due to tourism will have an impact on how people respond in the future, this depends on the nature and importance of tourism locally and the level of community interaction, their economic attitudes and dependence on it, and the character of tourists (Carmichael, 2000). Social and cultural impacts include three spaces in society, namely; tourists, communities, and forms of community relations with tourists (Mathieson \& Wall, 1982). However, while considering these impacts, it is important to recognize that communities in the tourism sector do not represent homogeneous groups (Brunt \& Courtney, 1999).

To understand community relations in tourism, it is important to note the aspects of how the two meet. Community responses to the impact of tourism formed from social contact between individuals (communities and tourists) from different cultural backgrounds can result in overall positive or negative attitudes, perceptions, and experiences (Tosun, 2002). Therefore the nature of this relationship is a major factor influencing the extent of its impact felt by the communities (Smith, 1989).

Sustainable tourism is mostly dependent on the perception of the surrounding community. This perception was built because they realized that the benefits derived from 
tourism (Lee, 2013). However, a positive perception from the community will accelerate the development of tourism. This perception influenced by demographic factors (which include age, sex, education level, and length of stay (Huh \& Vogt, 2008; Vargas-Sánchez, et al., 2009), bonds between citizens (Lee et al., 2013), tourism development planning (Choi \& Murray, 2010), and local economic conditions (Hunt \& Stronza, 2014; Lundberg, 2015; Diedrich \& García-Buades, 2009). The study shows how sustainable tourism from the point of view communities; this study focuses on the economic benefits it receives and how social impacts are (Gursoy et al., 2002). Some research results show that environmental impact is also a factor to measure sustainable tourism (Lee et al., 2013; Lundberg, 2015; Vargas-Sánchez et al., 2009; Diedrich \& García-Buades, 2009). Other indicators that can be used to measure sustainable tourism include politics, social, environment, technology, and culture (Choi \& Murray, 2010).

The development of tourism is dynamic. The pattern of development follows five primary stages, namely (1) exploration, (2) community involvement, (3) development, (4) consolidation, and (5) stagnation (Butler, 1980). At the exploration stage tourists come in small numbers and are serviced accidentally by the local community. Then along with the increasing number of visits, it will have an impact on the need for workers to serve tourism. The people involved then begin to feel the economic or social benefits of the tourism activities begin to develop to get more benefits. The next stage is the stability of the tourism management agency. A stage of stagnation generally follows this stage because the patterns of tourists or management that appear are no longer diverse. There are two possibilities after this stage, namely the decline or rejuvenation. The decline occurred due to the reluctance of managers to minimize negative environmental and social impacts. The result is a decrease in environmental and social quality that has an impact on the number of tourist visits. However, rejuvenation occurs if the manager develops from a new perspective by promoting sustainability. Tourists see this as a form of innovation and have an impact on increasing the number of visits.

In the early stages of community-based tourism (from now on referred to as CBT) development, the managerial pattern of the community on its environment will have an impact on its future (Sebastian \& Rajagopalan, 2008). Through proper planning, community-based tourism will improve the quality of life of the community, preserve local culture, and maintain biodiversity (Gurung \& Seeland, 2008). Improved quality of life derived from economic benefits. Multiple effects of economic benefits will make people aware that the culture or environment they live in can be an alternative source of livelihood. However, if tourism is not well-organized, eating may have a severe impact on the surrounding environment, such as environmental pollution and decreased biodiversity (Teh \& Cabanban, 2007). However, if these conditions continue, they will have an impact on the main livelihoods of communities (Lepp, 2007). Communities may tolerate this impact because of the economic benefits it receives (Diedrich \& GarcíaBuades, 2009). Therefore there needs to be sustainable tourism management.

To create sustainable tourism, managers need support from related parties such as tourism observers and university researchers to plan better. In developing countries such as Indonesia, relevant parties were mentioned accompanying communities in the form of education to manage their physical and social environment (RodríguezMartínez, 2008; Sebastian \& Rajagopalan, 2008), especially support from the government is needed to make regulations (Gurung \& Seeland, 2008).

\section{METHODS}

Design research used to explain how community understanding in sustainable tourism management is descriptive qualitative. The three stages of data collection begin 
with a preliminary study to design data collection instruments. The results of the preliminary study used to develop survey instruments to all tour managers in the buffer village of Baluran National Park (Figure 2). At the data collection session, a companion from the local manager helped to interview the subject. From the total of all managers, 53 interview data collected from managers and providers of tourism services between Marc to Sept 2019. This questionnaire was developed from a preliminary study in the form of observation to develop initial instruments. This observation then used to identify the reasons for the construction of a questionnaire distributed to communities and tourists as the second stage of data collection. The next phase consisted of a small number of indepth interviews with communities. The reason for doing the qualitative stage after quantitative allows respondents to comment on some of the initial findings in the interview and for triangulation, allowing the phenomenon to be seen from more than one source (Decrop, 1999; Davies, 2003). The integration of this data collection method provides several benefits and limitations. The main advantage is being able to observe the behavior of the situational nature (Veal, 1992), and the tourism environment directly rather than merely being inferred or remembered. The observation log was developed to enable general orientation (Moser \& Kalton, 1971) and systematically observe various dimensions and settings from expert sources. Data obtained from questionnaires and indepth interviews were then processed using a single tabulation descriptive analysis. Its function is to see the pattern of existing data and provide coding by the theme and case for natural reduction and presentation of data. The event-structure analysis is used to arrange the sequence of events that make it easier to see the causal relationship (Newman, 2017). This analysis will show the sequence of community involvement in developing tourism and the relationship between elements in it (Figure 1).

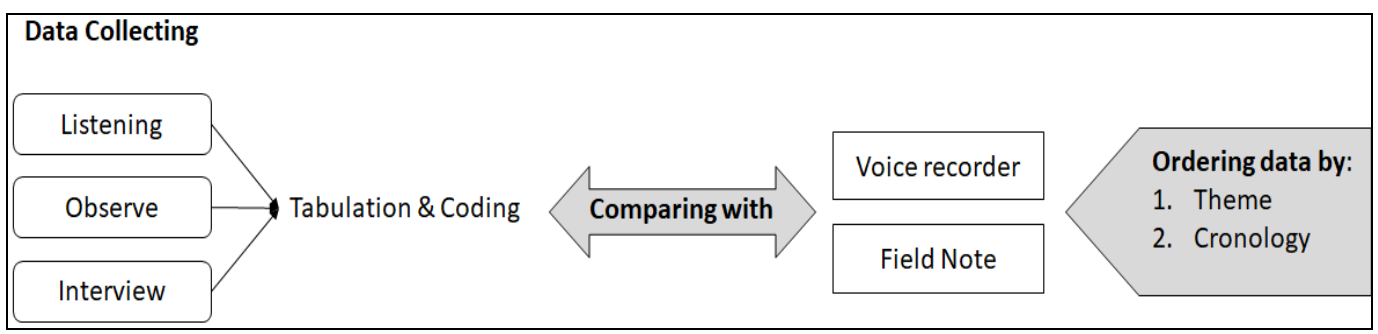

Figure 1. Data Analysis Diagram

\section{RESULTS AND DISCUSSIONS}

Baluran National Park was inaugurated in 1980 with a focus on the conservation of large mammals such as the Java Bull and Deer. The physiography is composed of materials that are limestone. Therefore, it is possible that the Baluran complex was the platform which then lifted. The Baluran is more like a plateau, which experiences a gentle breakdown which is more a result of the weathering and erosion processes than the folding process (Sastrohadi et al., 2014). To describe the process of communities managing the environment as a tourism destination, data collection aimed at managers from three buffer villages (Figure 2) tourism around Baluran National Park.

The three buffer villages have different characteristics, Sumberanyar - Situbondo is in the westernmost location of the park, the village is developing a tourist service in the form of a halfway house. Wonorejo village - Situbondo is at the eastern end of the park and is developing multicultural thematic tourism services. Then for Bajulmati Village Banyuwangi to develop supporting tourism services such as restaurants and alternative tourism in the form of Bajulmati reservoirs. The demographic conditions of the 
population in the buffer village of Baluran National Park were dominated by the workingage population (26-45 years) (Figure 3). However, with this potential workforce, their ability to provide tourism services is of moderate proficiency. This condition is because they lack training from experts. The skills they get come from direct experience serving guests who come and provide feedback. The services they provide are only lodging services for Baluran National Park visitors.

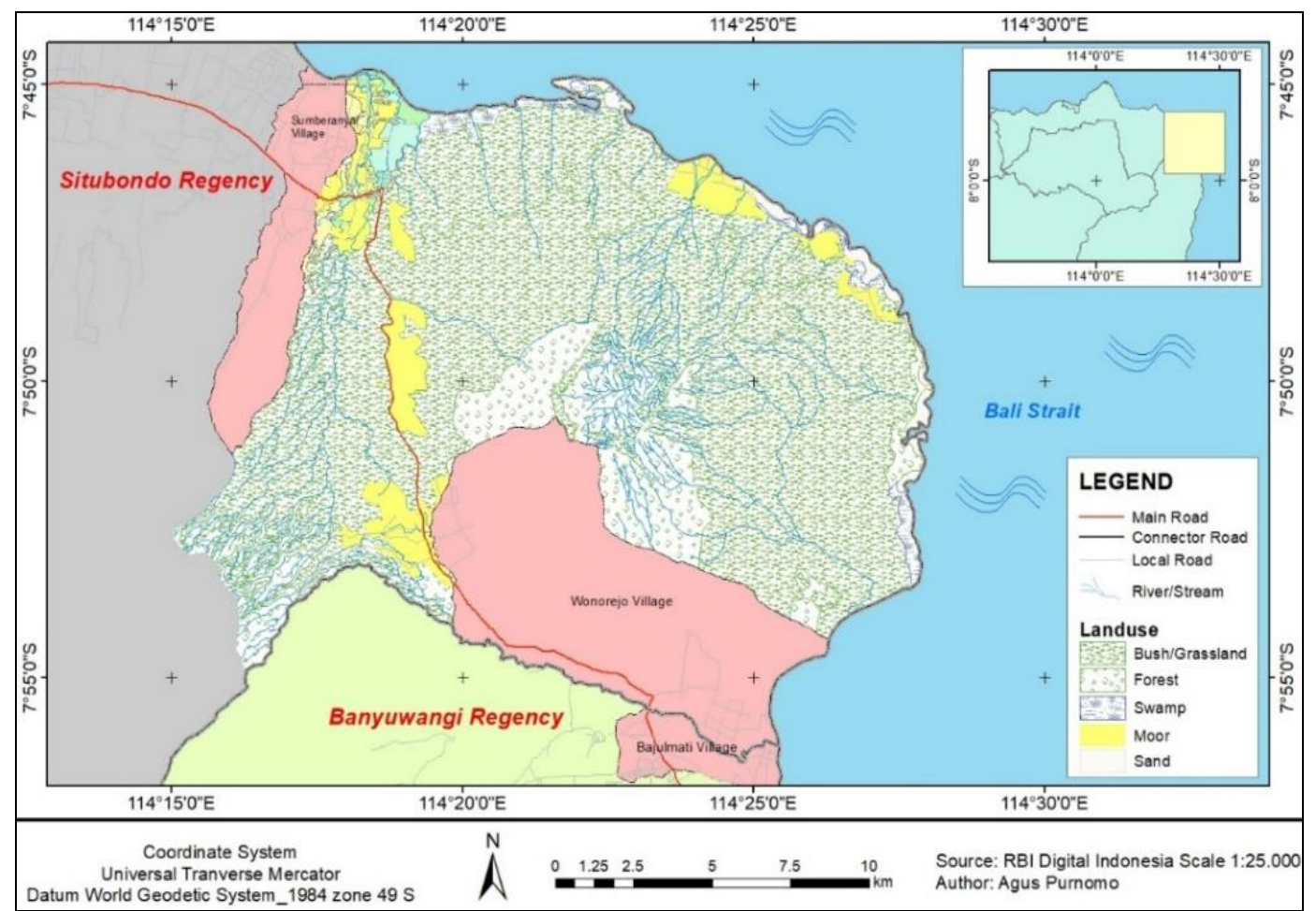

Figure 2. Baluran National Park Buffer Village

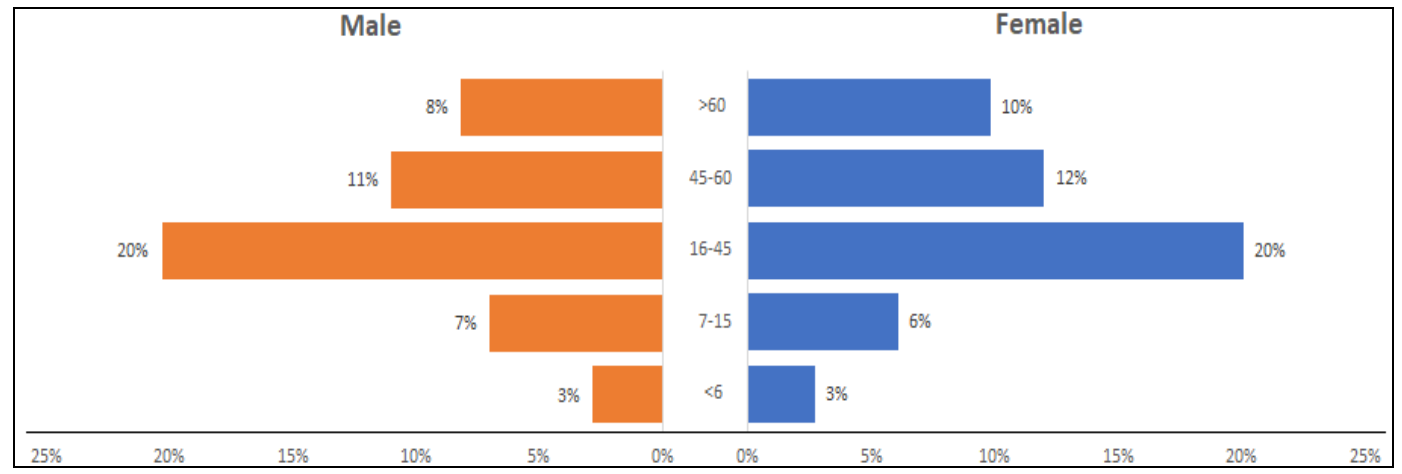

Figure 3. The composition of the population based on the age group of the buffer village of Baluran National Park

Tourist characteristics include four aspects, namely geography, physiography, demographics, and trends. Geographical aspects explain the tourists' origin. Origin of 
tourists can describe how the reach of publications or promotions that have been done by the manager or visitor satisfaction and disseminate the information (Arionesei \& Ivan, 2014; Brunt, 1997). the majority of tourists visiting the Ijen-Baluran KSPN are dominated by archipelago tourists from around East Java (56\%) and others from outside East Java with $5 \%$ from foreign countries. For tourists, access is not an obstacle to making visits but can be an obstacle (Abdulhaji \& Yusuf, 2016). Access to Baluran National Park is on the main route of Java-Bali, but the limitations of the attractions are the majority of the taste and try patterns that are dominated by young visiting groups, families (family trips), and some are doing research (field trips). The main function in the form of a conservation area is limiting tourist attractions/activities (Olsder \& Donk, 2006) that can be performed at this location. But the uniqueness of the prairie biome (pasture) is the main attraction.

The origin of tourists can also be one of the basic analysis of the development of attractions. Tourists who come will tend to look for souvenirs or find culinary specialties, or other things that make more time to spend time for his visit (Tang et al., 2009). Increased foreign tourist arrivals from abroad require managers to have foreign language skills in providing services (Agrawal \& Gibson, 1999; Purnomo et al., 2018; Salazar, 2012). Residents involved in tourism activities can also take advantage of the presence of foreign tourists if they have foreign language skills. Characteristics of tourists Baluran National Park visitors come with a group pattern (family/friends), which is dominated by unplanned visits. The age distribution of visitors and visit planning, the pattern of tourists who visit is dominated by taste and try tourists, family trips, and young travelers, this means that most of the visitors tend not to plan to return to this tourist location. One reason is because of the limited attractions/activities that tourists can do.

Some tourists expressed that one of the attractions of Baluran is an affordable ticket. Accommodation costs incurred by tourists only focus on the use of vehicle fuel consumption and consumption. The lack of tourism products in the form of souvenirs makes economic turnover to communities still minimal (Stynes \& Daniel, 2016; Du et al., 2016). For example, a local product that is around Baluran National Park in the form of processed cow's milk produced in the buffer village (Wonorejo Village, Situbondo), the problem is that they only carry out the compilation of orders. This production pattern makes consumers who come without promises of difficulties in getting the product intended. Based on the pattern of tourist visits to Baluran National Park, there are a total of six characteristics, namely cocoon traveler, family trip, field trip, taste and try, honeymooner, and young traveler (Table 1). Conclusion drawing of these characteristics is based on four aspects, namely geography, physiography, demographics, and trends.

The typology of visitors is one of the basics of tourism development and planning (Sarbaitinil \& Pristiwasa, 2018). Managers need to see where tourists are visiting, how their interests are, how to spend money, to the age of tourists who visit. One example is Bali, to facilitate visitors of old age, one of the managers provides senior tourism (Widyarini, 2017) to facilitate them. The reason is that this market segment is the most potential because most of them are retired workers who have money and time, so they tend to spend more time in tourist areas (Tang et al., 2009), this means that more money spent in tourist destinations. From the tourism development stage, the managers are still in the second stage (involvement). They are still working on how to increase the involvement of all elements of society to be involved in tourism activities. This second phase is still running for three years after the first five years (exploration).

The exploration phase began in 2010, after a crisis in the number of wild buffalo in the National Park. This crisis occurred because of a program run by the Natural Resources Conservation and Management Agency (BKSDA East of Java). In 1990, the number of wild buffaloes that were not native animals in Baluran National Park was more 
than native animals, namely the Java Bull and Deer. The manager is worried that if this condition continues, it will become an obstacle for the conservation of native animals. Therefore the manager decides the depopulation program by involving communities. Residents taught how to catch wild buffaloes for livestock or sale.

This method is an effective solution for both parties, low-cost management for the National Park to balance the animal population, and economic benefits for the local community in the buffer village. After the proportion of animals is proportional, the manager stops the wild buffalo depopulation program. However, the community's habit of obtaining new livelihoods from catching buffalo is challenging to break. In 2006 the manager issued a warning and threat of punishment for those who catch wild buffalo. Unfortunately, the number of wild buffalo catches does not decrease significantly from year to year. In late 2010 the manager changed the pattern by viewing the community as the second manager. Baluran National Park limits tourism services to visitors inside the park, and to get these services from communities in the buffer village. This policy resulted in the community starting to open halfway houses. In the five years of management, the community explores the potential that exists in their area as additional support and attraction. However, the process was slow because of limited knowledge about tourism management. They only develop it based on feedback obtained from visitors.

Tabel 1. Ijen-Baluran Tourist Typology

\begin{tabular}{|c|c|c|c|}
\hline \multicolumn{4}{|c|}{$\begin{array}{l}\text { Foreign tourists: The majority come from European countries such } \\
\text { as Germany and France, as well as from Australia, Malaysia, and Singapore }\end{array}$} \\
\hline No. & Physiographic & Characteristics & Trend \\
\hline 1 & $\begin{array}{l}\text { Interested in existing } \\
\text { forms of culture }\end{array}$ & $\begin{array}{l}\text { Cocoon travelers, Family } \\
\text { trip, Field trip }\end{array}$ & \multirow{6}{*}{$\begin{array}{l}\text { - Online travel booking services } \\
\text { - There is a special travel agent } \\
\text { - Interest in the natural beauty and } \\
\text { culture of the community } \\
\text { - There are promotional facilities in } \\
\text { the form of magazines, websites, or } \\
\text { newspapers and are equipped with } \\
\text { reviews of tourist destinations } \\
\text { - Demand for tourism needs is } \\
\text { increasingly complex and time and } \\
\text { experience-oriented }\end{array}$} \\
\hline 2 & $\begin{array}{l}\text { Interested in the natural } \\
\text { scenery of the prairie }\end{array}$ & Young travelers, Field trip & \\
\hline 3 & $\begin{array}{l}\text { Specific and accurate } \\
\text { information }\end{array}$ & Cocoon trevellers & \\
\hline 4 & $\begin{array}{l}\text { Choose a short trip and } \\
\text { move around }\end{array}$ & Taste and try & \\
\hline 5 & Travel in groups & $\begin{array}{l}\text { Field study, Family trip, } \\
\text { Honeymooners }\end{array}$ & \\
\hline 6 & Love photography & Young travelers & \\
\hline \multicolumn{4}{|c|}{$\begin{array}{l}\text { Local tourists: the majority are students who are studying in the City of Jember or communities around KSPN } \\
\text { such as Bondowoso and Banyuwangi, and the rest are from Jakarta, Yogyakarta, Central Java, West Java, and Bali }\end{array}$} \\
\hline No. & Physiographic & Characteristics & Trend \\
\hline 1 & $\begin{array}{l}\text { Interested in existing } \\
\text { forms of culture }\end{array}$ & $\begin{array}{l}\text { Young travelers, Family } \\
\text { trip }\end{array}$ & \multirow[t]{4}{*}{$\begin{array}{l}\text {-The trip is planned independently } \\
\text {-Interest in natural beauty }\end{array}$} \\
\hline 2 & $\begin{array}{l}\text { Interested in the natural } \\
\text { scenery of the prairie }\end{array}$ & Young travelers, & \\
\hline 3 & $\begin{array}{l}\text { Specific and accurate } \\
\text { information }\end{array}$ & Cocoon Travelers & \\
\hline 4 & Love photography & $\begin{array}{l}\text { Young travelers, Honey } \\
\text { Mooners }\end{array}$ & \\
\hline
\end{tabular}

The flexibility of community involvement results in consciously continuing to improve the quality of tourist services provided. Guest visits, such as students or village tourism managers also benefit from sharing management information. The results of this activity will be in the form of social exchange (experience and knowledge) in managing tourism (Lee \& Jan, 2019). Social exchange is an advanced form of manager 
interaction with tourists. This interaction shows that the community accepts tourism as part of their lives (Nunkoo, 2016). This acceptance makes tourism has a positive impact on the economy, social, and environment (Ward \& Berno, 2011). Interaction with tourists in the form of feedback will also provide insight into their hopes and needs (Chuang, 2010; Purnomo et al., 2018). Knowledge of the expectations and needs of tourists will have an impact on the ability of managers to improve their services. The need to improve services is based on the expectations of managers getting positive reviews from users (Rasoolimanesh et al., 2015). The need for this positive review is due to tourism trends shifting to digital information for reference (Browning et al., 2013). Digital tourism trends are a very effective marketing channel for tourism managers with low costs and extensive coverage (Castro et al., 2017; Királ'ová \& Pavlíčeka, 2015).

This exploration phase lasts until 2015. One of the buffer villages, Wonorejo Situbondo Village, has begun to develop thematic tourism, with the theme Kebangsaan Village. The main attraction offered is a harmonious life between religions in one area (Muslim, Christian, and Hindu). This stage indicates that the community has begun to engage in more coordinated tourism activities. They began to set aside the economic benefits they got to improve the quality of their services. However, in reality, the concept of thematic tourism concept is still unable to attract tourists to make it an alternative tourism Baluran Tourism Park (Figure 4). The main attractions are unable to attract tourists. They provide feedback so that managers develop tourism products that involve more visitors - such activities as gardening, or just sorting fish caught by fishermen on Pandean Beach. Preliminary studies show that tourism is an effective way to overcome the problem of poverty (Croes, 2014; Lepp, 2007). However, studies of the stages of tourism development managed by the community and the role of the government are still minimal. Through a study of the stages of tourism development, suggestions for a follow-up to managers will be better understood.

The economic benefits gained by the community are the main trigger for the second phase (community involvement). Tourism produces a variety of livelihoods that can be managed by them (Lepp, 2007; Diedrich \& García-Buades, 2009). Management carried out by the community to provide tourism services/products will continue to develop even without the support of the government. Because development can still occur from interactions with tourists when providing tourism services/products, this condition provides an opportunity to exchange knowledge (Uysal et al., 2012).

The pattern of people who are easy to imitate in providing tourism services/products in the first stage (exploration) will have an impact on competition. However, if managed correctly, they will become an active community. The benefit of having a community is the dissemination of benefits obtained from tourism activities. The community also provides a role in strengthening the carrying capacity of the social or physical environment (Lee \& Jan, 2019; Wahyuningtyas et al., 2019). The findings show that tourism activities increase the number of communities who are increasingly concerned with the preservation of the social and physical environment. They realize that the environment around their homes is an attraction for tourists (Lee, 2013).

The impact is the profits they get are partly invested in improving environmental quality (Uysal et al., 2012; Huh \& Vogt, 2008). Therefore at this stage, managers do not feel significant economic benefits. The economic benefits they get are prioritized for investment in quality improvement, and the aim is to increase the number of tourist visits (Uysal et al., 2012). In the future, an increase in the number of tourist visits will have an impact on managers' efforts to develop more diverse attractions. That stage (community involvement) will build a lot of negative or positive knowledge about the existence of tourism in the vicinity (Vargas-Sánchez et al., 2009). Positive knowledge is limited to how 
they benefit economically; meanwhile, negative knowledge formed from people's concerns about health aspects (tourists who carry infectious diseases when they go to their homes), security, or disruption to their personal lives. The role of the government to minimize internal conflicts due to differences in community knowledge is quite vital (Diedrich \& García-Buades, 2009). The government has the role of control through policies or increasing the ability of managers to provide tourism services/products. Policies produced to control the negative impacts of tourism activities must base on a study of the carrying capacity of the social or physical environment (Lee \& Jan, 2019).

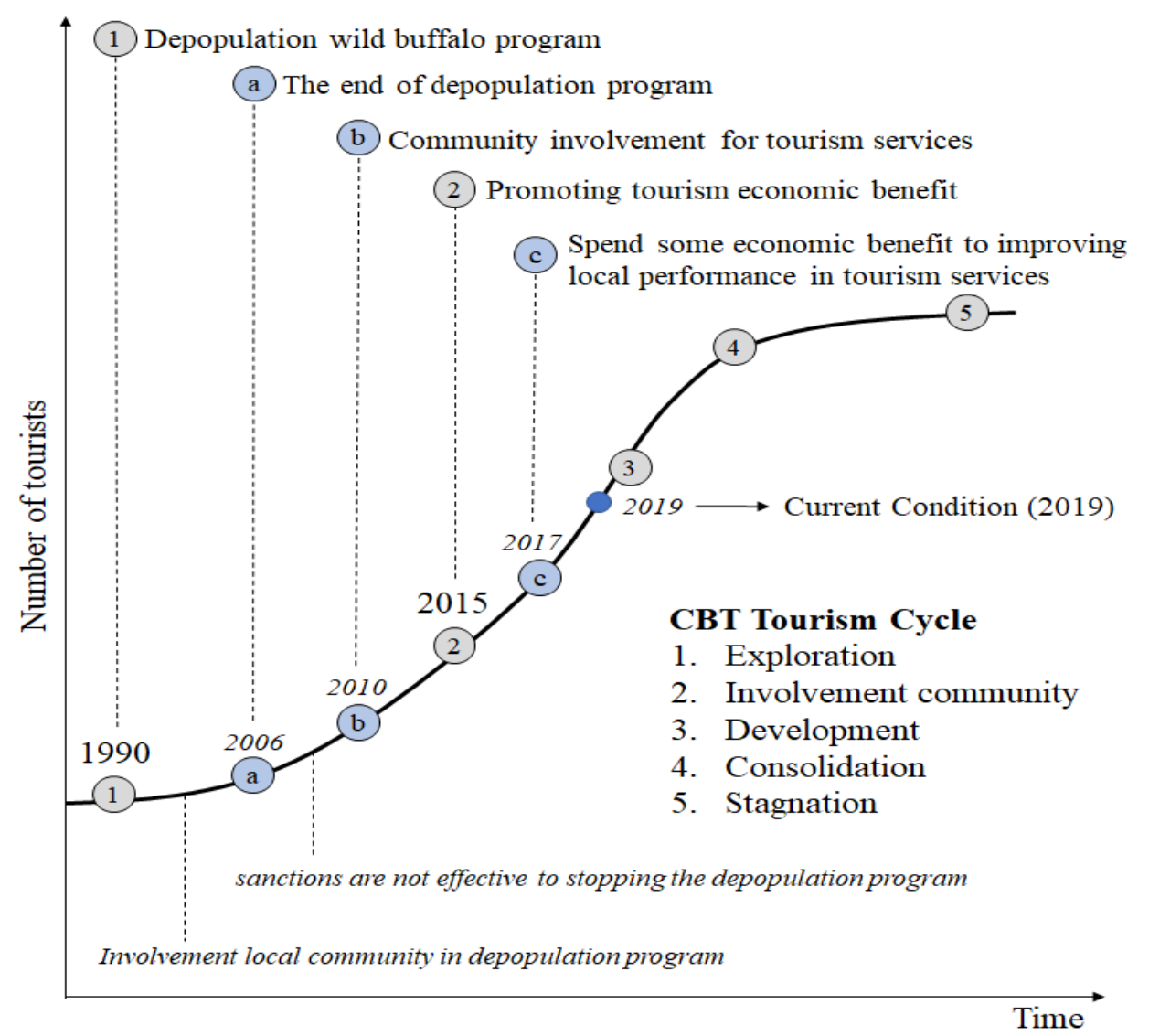

Figure 4. Conditions for the Development of Tourism in the Baluran Village Buffer Village (adapted from Butler, 1980)

Clear division of tourism zones can also minimize the negative impacts of tourism activities. The clarity in the location of settlements and tourism development areas will avoid the negative impression of disturbing people's private lives due to tourism (Diedrich \& García-Buades, 2009; Brunt \& Courtney, 1999). Zoning is also beneficial to protect the environment from excessive tourism activities (Bowers, 2016). The clarity of tourism zonation also contributes to the sustainability of tourism.

\section{CONCLUSION}

Based on the findings, the series of stages in developing community-based sustainable tourism focuses on the first two stages. After the exploration phase of tourism 
potential, managers must focus on the distribution of economic benefits to the communities involved. The distribution is in the form of developing supporting and educational facilities. The function is that they can independently promote tourism for further development. Education also plays a role in providing tourism services according to standards as well as producing unique tourism products such as crafts. However, because this research is only viewed from the aspect of economic benefits from the community's point of view, it is necessary to review how the local community as a whole.

At this stage, the availability of new employment opportunities for the community will increase their income. The distribution of economic benefits that were partly used for managerial knowledge investment will have an impact on the sustainability of tourism. They will be the frontline in protecting the social and physical environment. Simple forms such as putting up warning signs or directions from local guides will form a more responsible atmosphere. Such knowledge will also help divide tourism zones so that they do not mix with their daily lives. A further benefit is minimizing the conflict that can result from negative public perceptions about tourism.

\section{Acknowledgments}

This work was supported by PNBP research grant of Universitas Negeri Malang Under Contract No: SP DIPA 042.01.2.4000923/2019

\section{REFERENCES}

Abdulhaji, S. \& Yusuf, I.S.H. (2016). Pengaruh Atraksi, Aksesibilitas, dan Fasilitas Terhadap Citra Objek Wisata Danau Tolire Besar di Kota Ternate. Jurnal Penelitian Humano, 7(2), pp. 134-148.

Agrawal \& Gibson (1999). Enchantment and disenchantment: The role of community in natural resource conservation.. World Development, 27(4), pp. 629-649.

Arionesei, G. \& Ivan, P. (2014). Marketing of tourism destinations from the public relations' perspective. Journal of tourism, pp. 90-95.

Bowers, Jared. (2016). Developing sustainable tourism through ecomuseology: A case study in the rupununi region of Guyana. Journal of Sustainable Tourism, 24(5), pp. 758-782.

Browning, V., So, K.K.F. \& Sparks, B. (2013). The Influence of Online Reviews on Consumers' Attributions of Service Quality and Control for Service Standards in Hotels. Journal of Travel \& Tourism Marketing, 30(1), pp. 23-40.

Brunt (1997). Market Research in Travel and Tourism. Oxford: Butterworth-Heinemann.

Brunt \& Courtney (1999). Host perceptions of sociocultural impacts. Annals of Tourism Research, 26(3), pp. 493-515.

Brunt \& Courtney (1999). Host Perceptions of Sociocultural Impacts. Annals of Tourism Research, 26(3), pp. $493-515$.

Burkart \& Medlik (1974). Tourism Past, Present, and Furute, 2nd edition. Londong: Heinemann.

Bushell \& McCool (2007). Tourism as a tool for conservation and support of protected areas: Setting the agenda. In: Tourism and Protected Areas: Benefits Beyond Boundaries. Wallingford: CABI International, pp. 12-26.

Butler (1980). The concept of a tourist area cycle of evolution: Implications for management of resources. Canadian Geographer, 24(1), pp. 5-12.

Carmichael, B.A. (2000). A Matrix Model for Resident Attitudes and Behaviours in a rapidly Changing Tourist Area. Tourism Management, Volume 21, pp. 601-611.

Castro, S.R., Silva, S.C.E. \& DUarte, P. (2017). Does Digital Marketing really boost city tourism ? Evidences from Porto ' s Experience. European Journal of Applied Business Management, 3(3), pp. 84-100.

Choi \& Murray (2010). Resident attitudes toward sustainable community tourism. Journal of Sustainable Tourism, 18(4), pp. 575-594.

Chuang, S.T. (2010). Rural tourism: Perspectives from social exchange theory. Social Bahaviour and Personality an International Journal, 38(10), pp. 1313-1322.

Croes (2014). The role of tourism in poverty reduction: An empirical assessment. Tourism Economics, 20(2), pp. 207-226.

Davidson \& Sahli (2015). Foreign direct investment in tourism, poverty alleviation, and sustainable development: A review of the gambian hotel sector. Journal of Sustainable Tourism, 23(2), pp. 167-187.

Davies (2003). The Role of Quantitative and Qualitative Research in Industrial Studies of Tourism. International Journal of Tourism Research, 5(1), pp. 97-111.

Decrop (1999). Triangulation in Qualitative Tourism Research. Tourism Management, 20(1), pp. 157-161. 
Diedrich \& García-Buades (2009). Local perceptions of tourism as indicators of destination decline. Tourism Management, 30(4), pp. 512-521.

Dodds, Ali \& Galaski (2018). Mobilizing knowledge: Determining key elements for success and pitfalls in developing community-based tourism. Current Issues in Tourism, 21(13), pp. 1547-1568.

Du, D., Ng, P. \& Lew, A.A. (2016). Tourism and Economic Growth. Journal of Travel Research, 55(4), pp. 454-464.

Gursoy, Jurowski \& Uysal (2002). Resident attitudes: A structural modeling approach. Annals of Tourism Research, 29(1), pp. 79-105.

Gurung \& Seeland (2008). Ecotourism in Bhutan: Extending its benefits to rural communities. Annals of Tourism Research, 35(2), pp. 489-508.

Huh \& Vogt (2008). Changes in residents' attitudes toward tourism over time: A cohort analytical approach. Journal of Travel Research, 46(4), pp. 446-455.

Hunt \& Stronza (2014). Stage-based tourism models and resident attitudes towards tourism in an emerging destination in the developing world. Journal of Sustainable Tourism, 22(2), pp. 279-298.

Inskeep, E. (1991). Tourism Planning. New York: Van Nostrand Reinhold.

Jamal \& Stronza (2009). Collaboration theory and tourism practice in protected areas: Stakeholders, structuring and sustainability.. Journal of Sustainable Tourism, 17(2), pp. 169-189.

Királ'ová, A. \& Pavlíčeka, A. (2015). Development of Social Media Strategies in Tourism Destination. Procedia Social and Behavioral Sciences, Volume 175, pp. 358-366.

Lee (2011). How recreation involvement, place attachment, and conservation commitment affect environmentally responsible behavior. Journal of Sustainable Tourism, 19(7), p. 895-915.

Lee (2013). Influence analysis of community resident support for sustainable tourism development. Tourism Management, Volume 34, pp. 37-46.

Lee \& Back (2006). Examining structural relationships among perceived impact, benefit, and support for casino development based on 4 year longitudinal data. Tourism Management, Volume 27, pp. 466-480.

Lee \& Jan (2019). Can community-based tourism contribute to sustainable development? Evidence from residents' perceptions of the sustainability. Tourism Management, Volume 70, pp. 368-380.

Lee, Jan \& Yang (2013). Conceptualizing and measuring environmentally responsible behaviors from the perspective of community-based tourists. Tourism Management, Volume 36, pp. 454-468.

Lee, T.H. \& Jan, F.H. (2019). Can community-based tourism contribute to sustainable development? Evidence from residents' perceptions of the sustainability. Tourism Management, Volume 70, pp. 368-380.

Lepp (2007). Residents' attitudes towards tourism in Bigodi village, Uganda. Tourism Management, Volume 8, pp. 876-885.

Lundberg (2015). The level of tourism development and resident attitudes: A comparative case study of coastal destinations. Scandinavian Journal of Hospitality and Tourism, 15(3), pp. 266-294.

Mathieson, A. \& Wall, G. (1982). Tourism: Economical, Physical and Socail Impacts. Essex: Longman Group.

Moser \& Kalton (1971). Survey Methods in Social Investigation. (2nd ed). England: Dartmouth Publishing Company Ltd.

Newman, L. (2017). Metodologi Penelitian Sosial: Pendekatan Kualitatif dan Kuantitatif. 7 ed. Jakarta: Indeks.

Nunkoo, R. (2016). Toward a More Comprehensive Use of Social Exchange Theory to Study Residents' Attitudes to Tourism. Procedia Economic and Finance, pp. 588-596.

Olsder \& Donk, V.D. (2006). Destination Conservation: Protecting Nature by Developing Tourism, Netherlands: IUCN National Committee of The Netherlands.

Purnomo, A., Wiradimadja, A. \& Kurniawan, B. (2018). Pengembangan Destinasi Wisata Strategis Nasional Ijen-Baluran, Malang: Universitas Negeri Malang Fakultas Ilmu Sosial.

Purnomo, A., Wiradimadja, A. \& Kurniawan, B. (2019). Diversification of tourism product in KSPN Ijen. Jember, IOP Conference Series: Earth and Environmental Science, pp. 1-10.

Purnomo \& Listyo (2016). Perencanaan Paket Wisata Geo Ecocultural Park Taman Nasional Bromo Tengger Semeru di Kabupaten Malang, Malang: FIS Universitas Negeri Malang.

Rasoolimanesh, Jaafar, Kock \& Ramayah (2015). ARevised Framework of Social Exchange Theory to Investigate the Factors Influencing Residents'Perceptions. Tourism Management Perspectives, Volume 16, pp. 335-345.

Reggers, Grabowski, Wearing, Chatterton \& Schweinsberg (2016). Exploring outcomes of community-based tourism on the kokoda track, Papua New Guinea: A longitudinal study of participatory rural appraisal techniques. Journal of Sustainable Tourism, 24(8-9), pp. 1139-1155.

Rodríguez-Martínez (2008). Community involvement in marine protected areas: The case of puerto morelos reef, méxico. Journal of Environmental Management, 88(4), pp. 1151-116o.

Ruiz-Ballesteros (2011). Social-ecological resilience and community-based tourism: An approach from Agua Blanca, Ecuador. Tourism Management, 32(3), pp. 655-666.

Salazar, N.B. (2012). Community Based Cultural Tourism: Issue, threats and oportunities. Journal of Sustainable Tourism, 20(1), pp. 9-22.

Sarbaitinil \& Pristiwasa, I.W.T.K. (2018). Pengaruh tipologi wisatawan terhadap pengembangan pariwisata kota padang. Jurnal Kepariwisataan Dan Hospitalitas, pp. 183-193. 
Sastrohadi, J., Sianturi, R.S., Rahmadana, A.D.W, Maritimo, F., Wacano, D., Munawaroh; Suryani, T. \& Pratiwi, E.S. (2014). Bentang Sumberdaya Lahan Kawasan Gunungapi Ijen dan Sekitarnya. Yogyakarta: Pustaka Pelajar.

Scherl \& Edwards (2007). Tourism, indigenous and local communities and protected areas in developing nations.. In: Tourism and Protected Areas: Benefits beyond Boundaries. Wallingford: CABI International, pp. 71-88.

Sebastian \& Rajagopalan (2008). Socio-cultural transformations through tourism: Comparison of residents' perspectives at two destinations in Kerala, India. Journal of Tourism and Cultural Change, 7(1), pp. 5-21.

Shah, McHarry \& Gardiner (2002). Sustainable Tourism: Turning the Tide. Economic Briefing, London: UNEP.

Smith (1989). Hosts and Guests: The Anthropology of Tourism. Philadelphia: PENN.

Soekadijo (2003). Anatomi Pariwisata. Jakarta: Penerbit Gramedia Pustaka Utama.

Stynes \& Daniel (2016). Economic Impacts of Tourism, Michigan: Michigan State University.

Tang, L., Morrison, A.M., Lehto, X.Y., Kline, S. \& Pearce, P.L. (2009). Effectiveness criteria for icons as tourist attractions: a comparative study between the United States and China. Journal of Travel \& Tourism Marketing, p. 284-302.

Teh \& Cabanban (2007). Planning for sustainable tourism in southern pulau Banggi: An assessment of biophysical conditions and their implications for future tourism development. Journal of Environmental Management, 85(4), pp. 999-1008.

Thomson, Johnson \& Hanes (2016). Vulnerability of fishing communities undergoing gentrification. Journal of Rural Studies, Volume 45, pp. 165-174.

Tomoko \& Samuel (2009). Economic and Social Impact of Tourism on a Small Town: Peterborough New Hampshire. Journal of Scientific Research and Management, Volume 2, pp. 61-70.

Torkington, K., Stanford, D. \& Guiver, J. (2020). Discourse(s) of growth and sustainability in national tourism policy documents. Journal of Sustainable Tourism, 28(7), pp. 1041-1062.

Tosun (2002). Host Perceptions of Impacts: A Comparative Tourism Study. Annals of Tourism Annals, 29(1), pp. 231-253.

Uysal, Woo \& Singal (2012). The tourist area life cycle (TALC) and its effect on the quality-of-life (QOL) of destination community. In: Handbook of tourism and qualityof-life research. Netherlands: Springer , p. $423-443$.

Vargas-Sánchez, Plaza-Mejia \& Porras-Bueno (2009). Understanding residents' attitudes toward the development of industrial tourism in a former mining community. Journal of Travel Research, 47(3), pp. $373-387$.

Veal (1992). Research Methods for Leisure and Tourism : A Practical Guide. Harlow: Longman.

Vengesayi, S. (2003). A Conceptual Model of Tourism Destination Competitiveness and Attractiveness. Adelaide, s.n., pp. 637-647.

Wahyuningtyas, N., Tanjung, A., Idris \& Dewi, K. (2019). Disaster Mitigation on Cultural Tourism in Lombok, Indonesia. Geojournal of Tourism and Geosites, 27(4), pp. 1227-1235.

Walmsley, J.D., Boskovic, R.M. \& Pigram, J.J. (1983). Tourism and Crime: An Australian Perspective. Journal of Leisure Research, 15(2), pp. 136-155.

Wang, Carter \& Low (2016). Political challenges in community-based ecotourism. Journal of Sustainable Tourism, 24(11), pp. 1555-1568.

Ward, C. \& Berno, T. (2011). Beyond social exchange theory: Attitudes Toward Tourists. Annals of Tourism Research, pp. 1556-1569.

Stephen Leslie Wearing, Michael Wearing \& Matthew McDonald (2010). Understanding local power and interactional processes in sustainable tourism: Exploring village-tour operator relations on the kokoda track, Papua New Guinea. Journal of Sustainable Tourism, 18(1), pp. 61-76.

Widyarini (2017). Kelayakan Taman Ayun sebagai Destinasi Wisata Senior, Denpasar: Universitas Udayana.

Yachin, J. M. \& Ioannides, D. (2020). "Making do" in rural tourism: the resourcing behaviour of tourism microfirms. Journal of Sustainable Tourism, 28(7), pp. 1003-1021.

*** WTO (2002). Tourism and poverty reduction, Madrid: WTO.

Submitted:

19.11.2019
Revised:

03.04 .2020
Accepted and published online 14.04.2020 